\title{
Statistical and Econometric Analysis of Financial Indicators for Six Albanian Commercial Banks
}

\author{
Doc. Fiqiri Baholli \\ Professor in the Faculty of Economy and Agribusiness (AU Tirana) \\ Email: fbaholli@yahoo.com \\ Prof.As. Dr. Ines Dika \\ Professor in the Faculty of Economy and Agribusiness (AU Tirana) \\ Email: ines.dika@virgilio.it
}

Doi:10.5901/mjss.2014.v5n23p645

\section{Abstract}

The banking system in Albania has made important challenges during last 23 years. Intermediation of banks have served to Albanian economic development through lending and payments system, while mobilizing the savings of households and other financial sources. There are some studies on the tendencies and performance of main financial indicators for the banking system. However, these studies realized from supervisory authority (the Bank of Albania) are giving more information on aggregate level. Our study problem, in this article, is an approach on the development and performance of some banks in Albanian banking system. Our objective is to show how some important ratios of the banking system have evolved in time, the differences among the banks and in general their efficiency and performance. Data we are using are main financial indicators of 2009 - 2012 from six month series. The main ratios are: ROA (Return on Assets): X1 ROE (Return on Equity - net return after taxes): X2 Loans / Deposits: X3 Equity / Risk Weighted Assets: X4 Expenses / Revenues (expenses for one ALL1 revenue): X5 Non Performing Loans / Total Loans: Y The data used belong to Raiffeisen Bank, National Commercial Bank, Credins Bank, Intesa San Paolo, Alpha Bank, Procredit Bank.

\section{Albanian Banking System}

The commercial banking system in Albania at the end of 2013 have 16 banks operating into the following groups, as reported from the central Bank of Albania in "The Financial Stability Report" :

- Banks Peer Group 1 (each sharing 0-2\% of total banking sector's assets): United Bank of Albania, Veneto Bank, International Commercial Bank, First Investment Bank, Credit Bank of Albania,

- Banks Peer Group 2 (each sharing 2-7\% of total banking sector's assets): ProCredit Bank, Emporiki Bank, Branch of National Bank of Greece, Societe Generale Bank of Albania, Alpha Bank-Albania, Union Bank,

- Banks Peer Group 3 (each sharing over 7\% of total banking sector's assets): Raiffeisen Bank, Credins Bank, National Commercial Bank, Intesa Sanpaolo Bank-Albania, Tirana Bank.

As at end December 2013, by capital origin, the banks operating in Albania were dicided as follows:

- Austrian owned: Raiffeisen Bank,

- Italian owned banks: Intesa Sanpaolo Bank- Albania, Veneto Bank,

- Greek Owned banks: Alpha Bank-Albania Tirana Bank, Branch of National Bank of Greece,

- French owned banks: Societe Generale Bank-Albania, Emporiki Bank,

- Albanian owned banks: Credins Bank, Union Bank.

\section{Hypothesis}

Economic theory and logics shows that exist tight links among financial indicators. In this context we will try to verify an important economic link:

There in a linear correlation among percentage of NPL $(Y)$ on one side, with ROA X1, ROE X2, Loans to deposits X3, Equity to Risk Weighted Assets X4 and Expnses/Revenues X5, on the other side.

${ }^{1}$ ALL: Albanian Currency - Albanian Lek 
This is the hypothesis we are trying to verify.

\section{The Methodology Used Are:}

- Statistical: mainly averages and graphs,

- Econometric modeling.

\section{Theory Overview}

In general, the decision making in an enterprise is related with some financial sources, investments, expenditures and income. This decissions are based on information given by financial analysis which shows evidence on numerical expressions of financial, economical, technical and commercial relations. This management process "translates" in values the signals posted in balance sheet. In a way, that gives orientation to the management for objective achievements foreseen in its business plan (Shehu 2012)

Financial ratio analysis is a process that considers the evaluation of financial position of an enterprise in the past and recently. Its main objectives are the determination, forecasting and better evaluation of economic condition for the future performance (Karapici 2002). Financial analysis is a process of thinking, working and analyzing the accounting data, that creates an evaluation system for decision making.

Considering that users of financial data are stakeholders, the financial analysts make special efforts on the information collected from them. Most important stakeholders are equity investors, bond investors and banks (creditors) that ensure capital and operational resources for the enterprise.

Financial reports consist on collecting the information on financial statement, profit and loss, capital movement and cash flows of the enterprise. They present functional and timing process that occurs in an enterprise, assuring the basis for every rational analysis.

\section{The Balance Sheet}

The effectiveness of an enterprise management are reflected in its increasing level of assets or the decrease of liabilities, as well as the share of dividends (increase) on the net capital. These changes become evident by comparing assets and liabilities at the beginning and the end of a working period, giving though important information on enterprice's progress.

The Balance Sheet is reflection of financial situation of an enterprise at a certain time. It shows the size and the structure of asstes financed from different sources. Structure of asstes shows the direction of investments for the enterprise, while the structure of financial sources (liabilities) shows the effects of financial activities for the business.

The balance sheet at annual basis shows a general overview of assets and its liabilities to third parties, as well as liabilities to its shareholders (owners).

\section{The Profit and Loss Statement}

The results from activities of an enterprise are traditionally measured on its abilities to generate profits. In addition to the informations given from the balance sheet, managers owners and different analysts that use financial reports need the information on the profitability of activities for a period of time. These informations are given from Profit and Loss Statement.

The results from activities of an enterprise are traditionally measured on its abilities to generate profits. In addition to the informations given from the balance sheet, managers owners and different analysts that use financial reports need the information on the profitability of activities for a period of time. These informations are given from Profit and Loss Statement.

The Balance sheet and Profit and Loss statement, present two complementary documents that show the results of general activities of the enterprise. These documents present the comparison of sources generated for the business with the gains earned from this business. With the 'profit and loss' statement a business shows the financial result: profit/or loss realized during two comparative periods that are reflected from respective 'balance sheet' (normally reported as a fiscal year/period).

Financial result calculated in 'profit and loss statement' is posted on the balance sheet. This brings equal assets and liabilities on the Balance Sheet. 


\section{Cash Flow Reporting - Part of Financial Statement/Analysis}

Cash flow reporting is considered as one of the important information after the balance sheet and profit and loss statement. Enterprises that have insufficient monetary sources are having problems to meet their short term liabilities, while in longer term this can be turned to insolvency and bankruptcy. These situations are happening as projections for the future have mismatches between inflows and outflows of monetary means.

Cash Flow reporting shows in and outflow of monetary means that are realized from primary activities of the enterprise (operative, investment and financial activities).

Main objectives for the compilation of cash flow ratios are based on the information which ensure users of financial reports on the evaluation:

- Business abilities to generate money for financing of daily operations,

- Business abilities for the payment of principal and interest of loans, as well as the shareholders dividend,

- Business abilities for investments, equipment and sale of property that generates cash inflows.

The financial ratio analysis is dealing with the calculation and determination of ratios and links that exist on the balance sheet, profit and loss statement and cash flow, in a way that makes possible to correctly evaluate the financial position, success and liquidity of a business. The financial ratio analysis uses instruments like:

- Horizontal analysis,

- Vertical analysis,

- Main financial indicators analysis,

- Financial leverage analysis, etc.

Horizontal analyze shows the comparison of balance sheet statement at the beginning with the end of a fiscal year, as well as positions of the Profit and loss tatement for the respective periods. Comparative analyze is made for this year and previous year.

Vertical analyze of balance sheet and profit/loss statement is important because total position of balance sheet are considered as $100 \%$ and other items as a percentage. This is a structural financial reporting by making possible to the ratios to have common size basis.

The calculated ratios cannot show any result without the comparison with certain values taken as basis for analysis.

The analysis with indicators is presented in different financial ratios that are important to give information on the financial position of the enterprise. The ratio analysis is a practical tool of control in the financial management system, which makes possible:

- The directions of financial trends during operations of enterprise,

- The comparison of financial characteristics for our enterprise with other at the same activity (industry),

- The determination of links among the factors that have impact on financial success of an enterprise.

Comparison of ratios in different positions of the balance sheet and different periods can give many financial indicators for the activity of enterprise, and at the same time the main purpose for calculation of ratios is to give help for the management in planning, control and decision making.

Financial analysis is based on the ratio calculation, coefficients and indicators that are compiled. Simple mathematical formulas are used, but more important is the interpretation based in standards or norms (standards). The following interpretation standards are used for comparison:

- Abilities and experience of analysts based on their experience and knowledge,

- Comparison with the average of enterprises of the same activity or industry,

- Comparison with the historic indicators of the same enterprise (previous year/period)

- Comparison with the indicators and goals approved in the business plan,

- Standards approved in the literature.

The series of ratios are calculated to differentiate between at least four categories of ratios that focus on liquidity, activity, leverage and profitability. In general, liquidity indicates the firm's ability to meet short-term obligations and to continue operations. Activity ratios signal how efficiently a firm is using assets to generate sales. Leverage ratios indicate the mix of the firm's financing between debt and equity and potential earnings volatility. Profitability ratios provide evidence of the firm's sales and earnings performance. Basic ratios include the firm's return on equity, return on assets, profit margin, assets utilization, and sales growth rate (Koch, Timothy 2008). 


\section{The Level of some Financial Indicators}

The following graphs give the average level of 2009-2012 for some Albanian banks::

ROA (Return on Assets), X1

ROE (Return on Equity), $X 2$

ALL Loans / One ALL Deposits, X3

Capital / Risk Weighted Assets, X4

Expenses/ One ALL revenue, X5

Non-performing Loans/Total loans, $Y$

Graph 3.1: ROA graph, X1

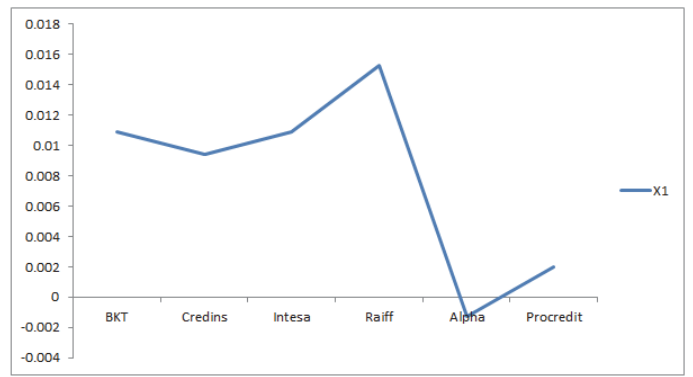

Raiffeisen Bank has higher return on assets, while Alpha Bank and ProCredit Bank have the lowest levels.

Graph 3.2: ROE Graph, X2

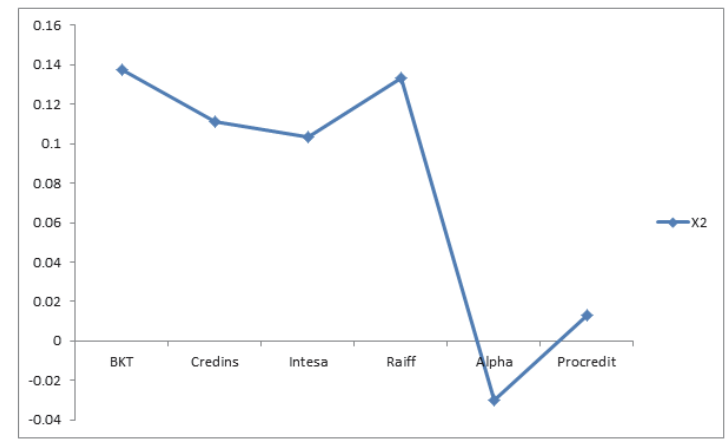

National Commercial Bank (BKT) and Raiffeisen Bank have higher levels on ROE. Alpha Bank and ProCredit Bank are still at the lowest levels.

Graph 3.3: Graph ALL Loan/ One All Deposits, X3

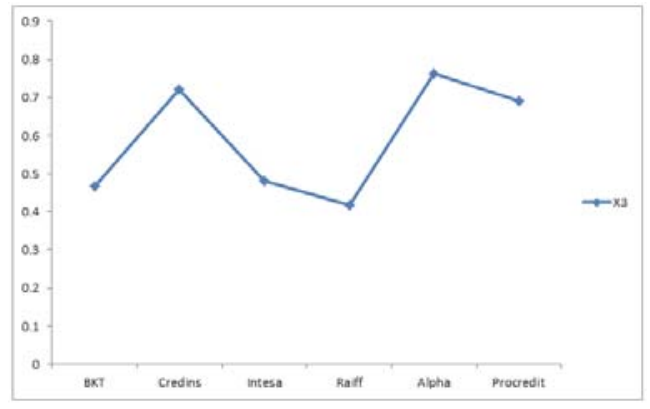

Alpha Bank, ProCredit Bank and Credins Bank have higher levels on X3, while at the lowest levels are Raiffeisen Bank and Intesa Sanpalo Bank. 
Graph 3.4: Graph Capital / Risk Weighted Asstes, X4

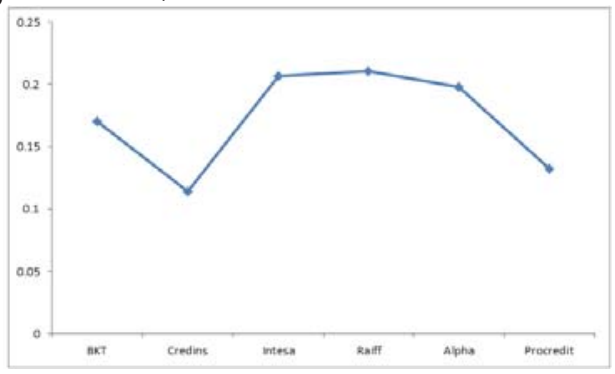

Credins Bank and ProCredit Bank are at low levels, while Intesa San Paolo and Raiffeisen Bank are at higher levels.

Graph 3.5: Graph of Expenses / One ALL Revenue, X5

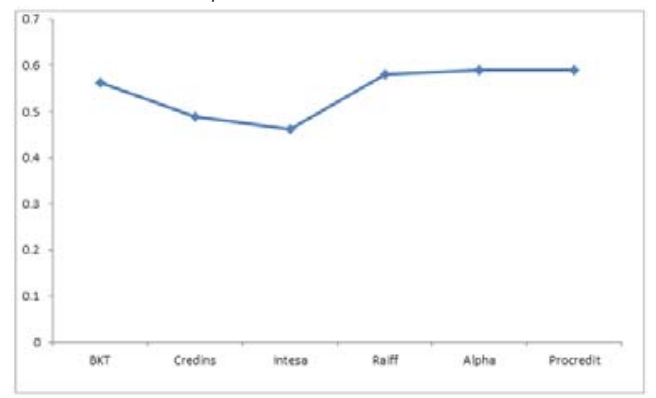

Intesa, Credins and BKT have at lower levels (better) this ratio, while three other banks stay at worse levels, almost the same value.

Graph 3.6: Graph of Non Performing Loans

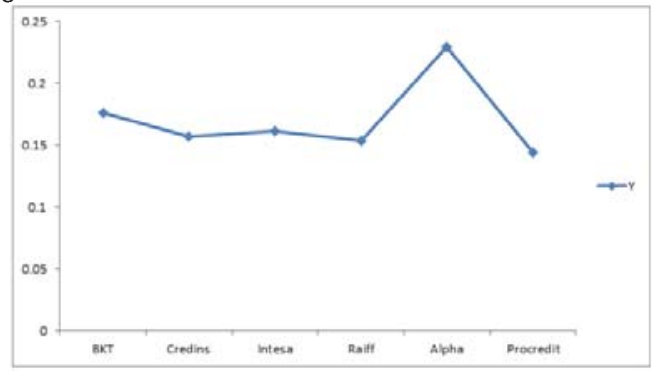

ProCredit and Raiffeisen are at low levels that means they have less nonperforming loans. Alpha Bank and National Commercial Bank (BKT) are having problems with nonperforming loans.

\section{The Trend of some Main Financial Indicators for 2009 - 2012}

The following graph shows the trends of indicators analyzed for the years $2009-2012$.

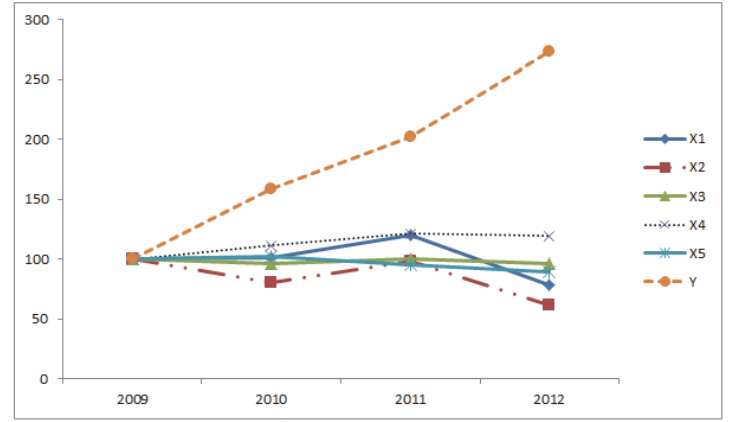


It is clear that the level of nonperforming loans $(Y)$ is increasing significantly last two years. The capital to risk weighted assets has a slight growing trend, while other indicators show a downdtrend.

\section{Econometric Model}

Based on our study hypothesis, we estimated the linear correlation of $Y$ with all other indicators $(X 1, X 2, X 3, X 4, X 5)$, using Eviews.

Table 4.1: The results of econometric model estimations with all factors.

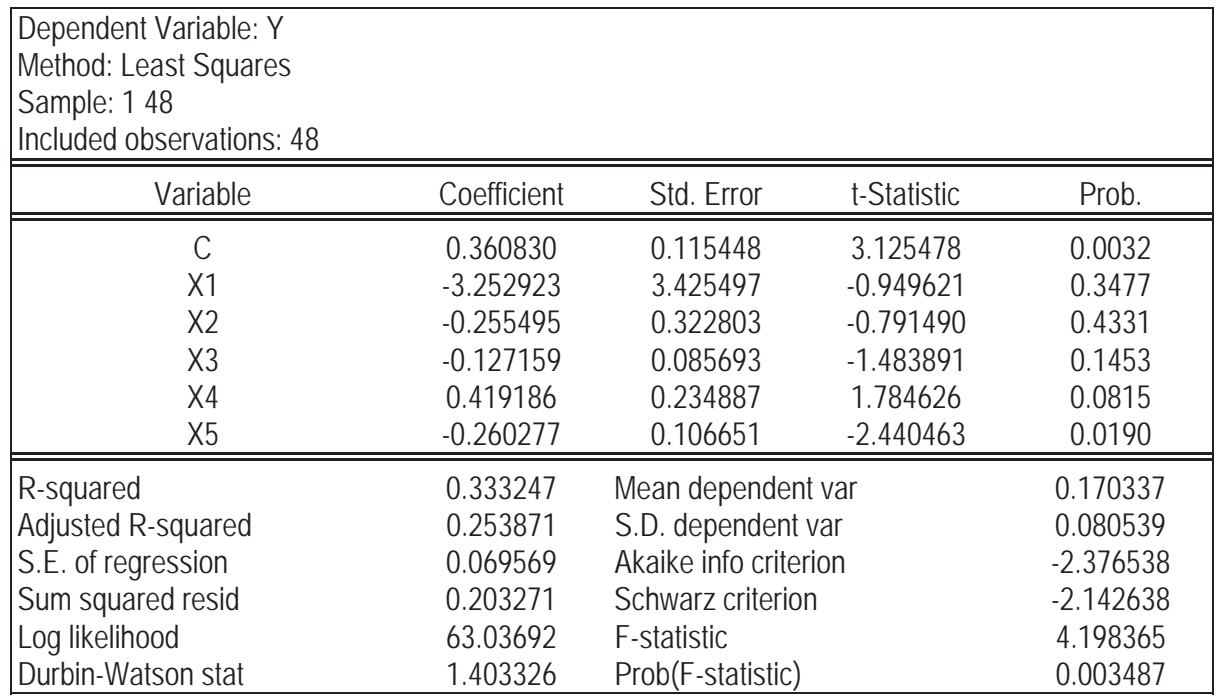

The model with all factors is:

\section{$Y=0.36-3.25 \times 1-0.26 \times 2-0.13 \times 3+0.42 \times 4-0.26 \times 5+e$}

The factors $\mathrm{X} 1, \mathrm{X} 2$ and $\mathrm{X} 3$ have not important correlation with $\mathrm{Y}$.

Following some applications, is verified the model with relevant factors $X 1, X 4$ and $X 5$ :

Table 4.2: The econometric model with significant factors

\begin{tabular}{|c|c|c|c|c|}
\hline $\begin{array}{l}\text { Dependent Variable: } \\
\text { Method: Least Square } \\
\text { Sample: } 148 \\
\text { Included observations }\end{array}$ & & & & \\
\hline Variable & Coefficient & Std. Error & t-Statistic & Prob. \\
\hline C & 0.221986 & 0.072209 & 3.074225 & 0.0036 \\
\hline $\mathrm{X} 1$ & -4.493806 & 1.420301 & -3.163981 & 0.0028 \\
\hline$X 4$ & 0.588248 & 0.209878 & 2.802814 & 0.0075 \\
\hline$\times 5$ & -0.215245 & 0.103380 & -2.082067 & 0.0432 \\
\hline R-squared & 0.293438 & Mean depend & & 0.170337 \\
\hline Adjusted R-squared & 0.245263 & S.D. depende & & 0.080539 \\
\hline S.E. of regression & 0.069969 & Akaike info $\mathrm{cr}$ & & -2.401880 \\
\hline Sum squared resid & 0.215408 & Schwarz crite & & -2.245947 \\
\hline Log likelihood & 61.64513 & F-statistic & & 6.091123 \\
\hline Durbin-Watson stat & 1.503805 & Prob(F-statist & & 0.001470 \\
\hline
\end{tabular}

The Model is:

\section{$Y=0.22-4.49 X 1+0.59 X 4-0.21 X 5+e$}

$\mathrm{X} 1$ ifluence is negative to $\mathrm{Y}, \mathrm{X} 4$ influence is positive, $\mathrm{X} 5$ is also negative. Though, the control of $\mathrm{X} 4$ results more important on bad debts management. 
The share of non-performing loans (NPL) is depended statistically from X1, X4 and X5. The low level of R-squared (Mean Dep. Var 29\% ) indicates that $Y$ is not is not influences only from X1, X4 and X5.

\section{Main Findings and Recommendation}

There are visible differences at the analyzed financial indicators among the banks.

Non-performing loans (NLP) are showing a positive trend which is a serious problem for Albanian banking system.

NPL indicator has important statistical correlation with some of financial indicators (X1, X4 and X5). In meantime low R-squared (Mean Dep.VAr. 29\%) shows that $Y$ is not depended only from X1, X4 and X5. NPL can be controlles significantly if $\mathrm{X} 1, \mathrm{X} 4$ and $\mathrm{X} 5$ are under control.

It is recommended a complete study that can find the full list of factors that influence NPL level.

\section{Literature and References}

Foundation of financial management, Stanley B.Block \& Geoffrey A.Hirt, N.York 2008

Bank management, Timothy Koch, S.Scot Makdonald, The Dryden Press 2009

Drejtimi Financiar, Halit Xhafa, Tirane 2008

Ekonometri me zbatime, Myslym Osmani, Tirane 2013

Analiza Financiare, Vjollca Karapisi, Tirane 2002

Analiza financiare, Hidajet Shehu, Tirane 2012 